\title{
Navigating complexity and uncertainty after the Belfast-Good Friday Agreement: the role of societal trauma?
}

\author{
Peter Doran
}

Queen's University Belfast

\begin{abstract}
A central challenge of the Belfast-Good Friday Agreement is the radical contingency or uncertainty that underpins the current democratic legal order in Northern Ireland. It is a dimension of the Agreement that will come to the fore with growing demands for preparations and planning abead of any referendum on the constitutional future of the region. Using a combination of perspectives from the literature on societal trauma and agonism, this article asks if we need to pay more attention to this affective dimension of the Belfast-Good Friday Agreement and the journey from outright antagonism to an agonism that envisages a society capable of addressing conflict while respecting the 'other's' entitlement to hold a radically different position.
\end{abstract}

Keywords: agonism; hegemony; the Belfast-Good Friday Agreement, contingency; complexity; 'culture of feeling'; politics and the political.

Suffering subsists on the underside of agency, mastery, wholeness, joy and comfort. It is, therefore, ubiquitous. 1

\section{Introduction}

The 100-year anniversary of the foundation of Northern Ireland in 2021 will be a testing time for the institutions of the Belfast-Good Friday Agreement ${ }^{2}$ as Ireland marks a 'Decade of Centenaries'. Approaches to the anniversary itself - sublime celebrations versus tragic commemoration - promise to be deeply contested, mirroring the polity's uncertain constitutional status.

Since the 2016 United Kingdom Referendum on leaving the European Union there has been a new conversation ${ }^{3}$ around the question of the pace and nature of political evolution in Northern Ireland, as fresh momentum in public deliberations about its

1 William Connolly, 'Suffering, justice and the politics of becoming' in David Campbell and Michael J Shapiro (eds), Moral Spaces: Rethinking Ethics and World Politics (University of Minnesota Press 1999) 125.

2 The Belfast Agreement - Agreement Reached in Multiparty Negotiations (Belfast 10 April 1998).

3 BBC News Online, 'PSNI chief warning over post-Brexit threat' (9 September 2018)

<www.bbc.co.uk/news/uk-northern-ireland-45461120>. The former Chief Constable of the Police Service of Northern Ireland, George Hamilton, accused some Westminster politicians of failing to understand the dangers of terrorism in Northern Ireland following the United Kingdom's departure from the European Union. 
contested constitutional status has been spurred by the unintended consequences ${ }^{4}$ of the referendum, alongside other constitutional uncertainties, including the timing and likely outcome of another referendum on Scotland's independence. ${ }^{5}$ Brexit and the United Kingdom-European Union negotiations that have flowed from the historic decision have dramatised the (geo)political entanglements that the Agreement sought to capture, codify and process with a view to bringing political violence to an end and creating the enabling conditions for a restoration of complex agency to political actors and citizens, above all, within Northern Ireland.

Using a combination of perspectives from the literature on the implications of societal trauma for post-conflict societies and the agonistics writings of Chantal Mouffe 6 and Bill Connolly, ${ }^{7}$ this article posits that the contingent nature of the constitutional configuration - represented by the Agreement - demands more attention to the affective challenge posed by the societal experience of trauma in the wake of violent conflict. A recognition of the importance of trauma as an affective dimension that can mediate political progress is part of a larger and growing appreciation of emotions in politics and law. Little and Rogers ${ }^{8}$ note that the shift to a concern with the emotions in politics is a recognition that how people feel in and after violence constitutes more than a sideshow that detracts attention from rigorous analysis of policy initiatives or institutional reform. The emotive dimension must be included in political analysis in recognition of the capacity of people - both individually and collectively - to reinforce or undermine institutions and policies.

Noting that the experience of trauma is closely linked to the role of language and narrative in the constitution and stabilisation of identity, Little and Rogers describe trauma as the experience of an excess resulting from the impossibility of assimilating a loss or suffering into one's narrative. The victim or survivor is the one who struggles to tell the story that cannot be captured in thought, memory or speech. ${ }^{9}$ In conditions of conflict, the political symptomology rooted in the trauma of a society that has experienced violence - a desperate effort to fix one's own categories, while refusing those of others - can clash with the imperatives of engaging with the complexity of a conflict and is both prolonged and reproduced by the experience of contingency and uncertainty. Traumatic symptomology clashes with the demands for a new kind of citizenship in

4 Peter Robinson, 'Professorial Speech from Right Honourable Peter Robinson' (8 June 2018)

<qpol.qub.ac.uk/professorial-speech-rt-hon-peter-robinson>. In his professorial lecture at Queen's

University, Belfast, the former leader of the Democratic Unionist Party, Right Hon Peter Robinson, became an unlikely proponent for the examination of and reflection on the issue of the border poll instrument, as set out in the Belfast-Good Friday Agreement. It should be added that his comments were couched in a statement of his own confidence that such a poll will result in the status quo. Nevertheless, noting the chaotic experience that has followed in the wake of the United Kingdom's Brexit referendum, he called for early consideration and agreement on a process of negotiations, timescales and the identification of who would be involved in negotiations on an Irish border poll and its outcome, to avoid the kind of chaos and disruption that has followed the 2016 Brexit debacle.

5 Politico, 'Support for Scottish independence at highest ever level: poll' (14 October 2020). A series of polls in 2020 point to a consistent majority in favour of Scotland leaving the United Kingdom.

6 Chantal Mouffe, Agonistics - Thinking the World Politically (Verso Books 2013) 306.

7 Connolly (n 1).

8 Adrian Little and Juliet Brough Rogers, "The politics of "whataboutery": the problem of trauma trumping the political in conflictural societies' (2017) 19(1) British Journal of Politics and International Relations 172, 173.

9 Dori Laub, 'An event without a witness: truth, testimony and survival' in Shoshana Felman and Dori Laub (eds), Testimony: Crises of Witnessing in Literature, Psychoanalysis and History (Routledge 1992) 75, cited in Little and Rogers (n 8). 
Northern Ireland, one that is less grounded in certainty and more at ease with the fluidity and virtuosity of pluralisation, with horizons that extend to ever new constellations of identity/difference.

The parties and their constituencies within Northern Ireland have never been the definitive authors of their fateful constitutional narratives (whether nationalist or unionist), and - as the structures and logics of the Agreement attest - they could never become the sole authors of the definitive resolution to an essentially (geo)political dilemma bestowed by the failures of the United Kingdom and the Republic of Ireland to win lasting legitimacy for their now qualified claims on the territory. Sectarianism has always been the shadow play of an underlying crisis of agency, based on a misrecognition of the complex locus of effective intervention: a combination of local and non-local factors. Harvey has noted that it was never envisaged that an 'internal' Northern Ireland solution could or would work. ${ }^{10}$ This explains, for example, the design of the Strand One institutions to operate within overarching confederal and federalising arrangements or possibilities guaranteed by the 'patron' states. ${ }^{11}$ Crucially, O'Leary observes that these over-arching arrangements, with their prospects of shared authority, have been largely downplayed during the life of the Agreement.

The British-Irish Agreements recognition of the legitimacy of whatever choice is freely exercised by a majority in Northern Ireland with regard to its status, whether they prefer to continue to support the union with Great Britain or a sovereign united Ireland, underwrites the radically contingent nature of Northern Ireland's status in recognising that the most fundamental constitutional question remains open-ended. By institutionalising uncertainty in the terms of the Agreement, the two governments bestowed a far-reaching challenge on parties and communities emerging from a traumatic generational experience of violent conflict and societal instability.

In promising rigorous impartiality in their protection of rights and institutions the two governments also, indirectly and implicitly, assumed responsibilities to ensure that the politics of Northern Ireland could never again be allowed to lapse into a sectarian standoff on the old 'narrow ground'. ${ }^{12}$ Any failure by the two governments to remain fully engaged and impartial has always risked - by default - licensing if not encouraging an element of recidivism in the internal politics of the region (Strand One), given that the terms of the extraterritorial dimensions of the Agreement have met with some resistance from parties operating within Northern Ireland. ${ }^{13}$ This has been borne out by a constant need for Irish and British governmental interventions to assist the Northern Ireland parties during periods of crisis and suspension. ${ }^{14}$ The guardianship commitment by the two governments - the outworking of improved British-Irish relations during the 1990s - was a formative factor in enabling the Agreement and will have to be translated into a sustained process of deep engagement with political and civic society in Northern Ireland if the dominant ethno-nationalist parties working in the Strand One institutions are to be encouraged to embrace a more complex and nuanced form of identity politics at the

10 Colin Harvey, 'Leaving the union: Brexit and complex constitutionalism in Northern Ireland' (2018) 11-12 Irish Yearbook of International Law.

11 Brendan O'Leary, 'The twilight of the United Kingdom and Tiochfaidh ár lá: twenty years after the Good Friday Agreement' (2018) 17(3) Ethnopolitics 3.

12 A T Q Stewart, The Narrow Ground: Aspects of Ulster, 1609-1969 (Blackstaff Press 1997).

13 The Democratic Unionist Party not only opposed the signing of the Belfast-Good Friday Agreement but have continued to resist wholehearted participation in the cross-border institutions. Unionists have occasionally exercised vetoes to contain any expansion in competences.

14 O’Leary (n 11) 5. 
scales and levels of political activity where formative shifts in power and influence are registered with a sobering clarity. Brexit, for example, has helped to accelerate an emergent renegotiation of patterns in political relationships both within the United Kingdom (the 'Empire State'), ${ }^{15}$ driven by a re-emergence of a newly assertive English identity, and a repositioning of the United Kingdom - outside the European Union - in international relations.

Participation in a complex interdependency of scales and boundaries is written into the Agreement, namely the three Strands that must be understood as dynamic and openended entanglements and relationships in which identities and meanings continue to unfold and evolve as functions of power shifts. This original transversal logic of the Agreement is an admission that the political theatre or space of Northern Ireland, as constituted before 1998, was unable to 'safeguard the space in which antagonistic social forces have failed to subdue one another'. ${ }^{16}$ The Agreement recast the constitutional ${ }^{17}$ space as a series of institutionalised North-South-East-West Anglo-Irish relationships in ways intended to enable the conflicting parties within Strand One to cultivate conditions for agonistic respect, ${ }^{18}$ while navigating contingency as a way of political life. The Agreement reintroduced an explicit recognition of the (geo)political as the decisive theatre for staging the non-violent resolution of outstanding differences. Agonistic respect is complex, all the more so when radical contingency - in terms of contested constitutional outcomes - is part of the Agreement's DNA. It demands more than institutional layers of deliberation. It also demands the cultivation of what Williams ${ }^{19}$ once described as a 'culture of feeling', that inner dynamic at work by means of which new formations of thought emerge to replace dominant or once hegemonic ways of thinking. Nancy 20 cautions that shared structures of feeling must not be automatically identified with those that are experienced in common or as a structure through which the same feelings are derived. Instead, Nancy insists that a truly shared structure of feeling is one in which actors have a distinctive, contributory stake - a structure that incorporates and enables the activation and further articulation of differences. In the context of the conflict in Northern Ireland these shifts in hegemonic influences that have borne down on the territory since its foundation (and on the island of Ireland for much longer) are only fully understood and fully experienced across all three theatres or Strands of the Agreement. There has never been a realistic prospect that constituencies or parties might be swept up indistinguishably into a compelling shared narrative - the experience of essentially being the same. The Agreement's affective challenge is a demand for the cultivation of a shared structure of feeling in which the parties retain a distinctive, contributory stake, incorporating and enabling the activation of difference in a spirit of respect.

Williams was all too aware of the apparent contradictions in bringing together the words 'structure', with its associations with fixity and objectivity, and 'feelings', denoting affect, fluidity and subjectivity. His conceptual work on 'structure of feeling' was an attempt to draw attention to emergent relational dynamics, to that structuring process that is synonymous with a quality of historically distinct social experiences and relationships-in-solution. Understood as such, as a structuring process, the Agreement brings the affective and the cognitive dimensions of consciousness and relationality into

15 Anthony Barnett, The Lure of Greatness: England's Brexit and America's Trump (Penguin Books 201).

16 William Connolly, Ethos of Pluralization (University of Minnesota Press 1995) 115.

17 Robinson $v$ Secretary of State for Northern Ireland and Others [2002] UKHL 32.

18 Andrew Schaap, Law and Agonistic Politics (Ashgate Press 2009).

19 Raymond Williams, Marxism and Literature (Oxford University Press 1977).

20 Jean Luc Nancy, The Inoperative Community, Simona Sawhney (trans) (Minneapolis University Press 1991). 
dialogue, in bringing elements of impulse, restraint, tone and tension into an abiding and continually changing constellation. The discernment process that must accompany the Agreement - entailing a culture of feeling - is not about an encounter with an already established set of fixed institutions or societal templates but, in Williams' words 'social experiences in solution, as distinct from other social semantic formations which have

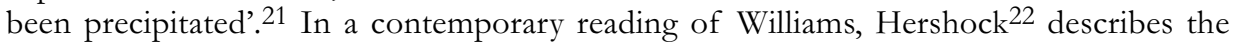
possibility of a politics of diversity that can be understood as a still-emerging structure of feeling at once resulting from and resulting in ongoing amplifications of differences as the basis of mutual contribution - a structure of feeling that is non-dualistic but essentially relational, and dynamically aligned with an appreciation of strengths for relating freely. Far from implying or implicating constituencies in a fixed institutional framework the politics of diversity demanded by the Agreement also invites a coalescence of differentially realised patterns of ever-strengthening readiness for shared, valuegenerating relational improvisation.

Human or social systems contain both designed (Strands One, Two and Three) and emergent (informal networks, civil society) structures. The designed structures include legal and institutional forms of routinisation and predictability, while the key emergent structures - where novelty and innovation is more likely to emerge - are created by informal networks and communities of practice (in law, business, peace activism, therapeutic practitioners). The emergent dimension is akin to a living system and is key to innovation, creativity and flexibility. The emergent dimension is also the realm of the affective, the domain where emotion encounters and comes into conversation with what has been routinised and what is now possible. This is also a domain that is associated with non-linear change, involving multiple feedback loops across scales of organisation and resistance to pre-determination.

\section{Origins of the question}

The question raised in this article was first articulated at a Northern Ireland Roundtable on Wellbeing, a high-level stakeholder process that met over the course of two years (2014-2015) to consider recommendations for the design of an outcomes-based performance framework for the Northern Ireland Executive's draft Programme for Government ${ }^{23}$ (2016-2021). The Roundtable was convened by the author ${ }^{24}$ together with the Carnegie United Kingdom Trust. One of the first discussions taken up by the stakeholders - drawn from two of the main political parties, the senior civil service, academia and civil society - was the mental health impact of the conflict on the population. The Roundtable ${ }^{25}$ addressed wellbeing in a post-conflict context, noting that it is linked to enhanced levels of political agency, capabilities, autonomy and embedding a culture of democratic deliberation. At the first meeting of the Roundtable, considerable attention was given over to the collective traumatic impact of the conflict and the consequences for levels of mental health and addiction. Participants linked contemporary experiences of trauma, addiction, self-harm and suicide and our collective incapacity to complete the journey out of enmity.

21 Williams (n 19) 132-133.

22 Peter Hershock, Valuing Diversity: Buddhist Reflections on Realizing a More Equitable Global Future (Suny Press 2012) 251.

23 Northern Ireland Executive, Draft Programme for Government 2016-21 (Northern Ireland Executive 2016) 7 <www.northernireland.gov.uk/topics/work-executive/programme-government>.

24 Together with John Woods.

25 Peter Doran, John Woods and Jennifer Wallace, Towards a Wellbeing Framework for Northern Ireland: A Technical Report (Carnegie United Kingdom Trust 2015) 29-32. 
The Belfast writer and campaigner, Adam McGibbon, has noted ${ }^{26}$ that Northern Ireland has recorded the highest rates of post-traumatic stress disorder in the world, with 40 per cent of the population having experienced a conflict-related trauma event. He attributes this to the 'scars of the Troubles, our decades-long conflict, and the unsolved problems left in its wake'. One of the key indicators of ongoing and widespread psychological fallout is Northern Ireland's prescription rates for antidepressant medicines. Research ${ }^{27}$ conducted in 2014 for the data-based journalism project, The Detail, reinforced earlier findings about the consumption of prescription medication.

Research conducted by Professor Mike Tomlinson at Queen's University Belfast has also linked the increase in suicide in Northern Ireland to the legacy of 'the Troubles', with a key finding that the cohort of children and young people who grew up in the worst years of violence, during the 1970 s, recorded the highest and most rapidly increasing suicide rates and account for a steep upward trend in suicide following the Agreement. ${ }^{28}$ Tomlinson's findings are reinforced in a survey by the University of Ulster. The survey results state:

The highest odds ratios for all suicidal behaviours were for people with any mental disorder. However, the odds of seriously considering suicide were significantly higher for people with conflict and non-conflict-related traumatic events compared with people who had not experienced a traumatic event. ${ }^{29}$

In 2020, the Northern Ireland Executive took a number of steps to address a perception that mental health and its impact on wellbeing remain priority concerns, including suicide prevention. The Executive established a special working group on mental wellbeing, with Deputy First Minister Michelle O’Neill noting that these complex issues should be addressed by a number of departments beyond the Department of Health. ${ }^{30}$ In June 2020, the Health Minister went further and announced the appointment of an interim mental health champion, Professor Siobhan O’Neill, of Ulster University. ${ }^{31}$

26 Adam McGibbon, 'Coronavirus could bring Northern Ireland's mental health crisis to boiling point (mww.inews.co.uk, 17 August 2020) <www.inews.co.uk/opinion/coronavirus-northern-ireland-mental-healthptsd-boiling-point-579467>.

27 Jon McClure, 'New data shows Northern Ireland is a world leader in prescription drug use' (The Detail 17 November 2014) <www.thedetail.tv/articles/new-data-shows-northern-ireland-is-a-world-leader-inprescription-drug-use $>$. The Detail reported, inter alia: 'Antidepressant prescription rates in Northern Ireland far exceeded those of England and Wales, and were also higher than levels found in 23 countries featured in a global study; Northern Ireland's prescription levels are higher than other United Kingdom regions with a similar economic profile, or with similar or higher rates of depression; Doctors interviewed for the Script Report pointed to a rising problem among age groups that are too young to have directly experienced the Troubles.'

28 Mike Tomlinson and G P Kelly, 'Is everybody happy? The politics and measurement of national wellbeing' (2013) 41(2) Policy and Politics 139.

29 Paul Nolan, The Northern Ireland Peace Monitoring Report 3 (Northern Ireland Community Relations Council 2014) <www.community-relations.org.uk/wp-content/uploads/2013/11/Introduction1.pdf>.

30 The Northern Ireland Executive Committee, 'Executive will work together to improve mental health Ministers' (Northern Ireland Executive Committee 22 January 2020) <www.executiveofficeni.gov.uk/news/executive-will-work-together-improve-mental-health-ministers $>$.

31 Northern Ireland Executive Committee, 'Appointment of interim mental health champion' (Northern Ireland Executive Office 24 June 2020) <www.health-ni.gov.uk/news/swann-announces-appointmentinterim-mental-health-champion $>$. In a press release issued by the Northern Ireland Executive Committee the Health Minister set out the responsibilities of the interim mental health champion, including: participation in the public debate around mental resilience, suicide, mental health and recovery; building consensus to integrate mental health and wellbeing across government and its integration into public policy making; and to advise senior stakeholders, support research and provide a voice for those who otherwise would not be heard. 
While the steps being taken by the Northern Ireland Executive are clearly an advance in recognising and acting on the psychic fallout of the political conflict and the resulting sequelae, the wider political implications of a traumatic interruption of a society's already contested narrative(s) is a key concern here. An important figure for understanding these implications is Paul Ricoeur, for whom humanity's collective existence itself is constituted by narrative. In a post-conflict setting it is the relationship between the personal and the political or shared narrative that is of particular interest if we are to understand the significance of post-conflict trauma. Ricoeur has influenced the thinking of the President of Ireland, Michael D Higgins, in his invocation of 'narrative hospitality', 32 a taking of responsibility in imagination and in sympathy for the story of the other, through the life narratives which concern the other.

Trauma cannot be reduced to an individualised symptom of conflict but is implicated, as Jenny Edkins and others have shown, in our very understanding of sovereign political power and the political. The Northern Ireland Executive's tentative steps to address mental health barely begin to identify this larger picture where trauma poses an affective interruption of the possibilities for politics per se given its role in mediating memory and the constitution of sovereign political communities. Of particular relevance for a transversal territory like Northern Ireland is Edkins' examination of the under-analysed 'traumatic intersection between peace and war, inside and outside' - the existential realm between the internal working of the state and international politics - with its concern for external conflict and war, and the implications for the production of the self and the state. These observations have a special importance for the region because the contingent and radically uncertain conditions that have suffused politics since the Agreement are - in a fundamental sense - a politics of suspension, a suspension between war and peace, a suspension between the linear norms associated with the internal workings of a state (politics) and the discontinuous (ab)normality of the sphere of (geo)politics or 'anarchy' (the political). ${ }^{33}$ It is this state of suspense - and contingency - that complicates the experience of trauma, conflict and politics in Northern Ireland.

\section{THE NATURE AND ROLE OF TRAUMA IN POST-CONFLICT POLITICS}

Trauma is perceived to inhabit post-conflict societies. ${ }^{34}$ For Little and Rogers, ${ }^{35}$ conflictual societies attempting to deal with troubled histories through legal and political reform often have to confront the residues of trauma that accompany protracted violence and bloodshed. In conflicts located in long histories of political difference, a focus on the traumas acquired through the violence of the past is crucial.

Theorists of trauma ${ }^{36}$ note the paradox that the most direct seeing or witnessing of a violent event may be experienced as an absolute inability to know it. The immediacy sparks a belatedness and, since traumatic experience enters the psyche differently than normal experience and creates an abnormal memory that resists narrative representation, the unique process of this remembering results in an approximate recall but never determinate knowledge. Traumatic memory gives rise to an inherently unstable and indeterminate set

32 Paul Ricoeur, 'Reflections on a new ethos for Europe' in Richard Kearney (ed), Paul Ricoeur: The Hermeneutics of Action (Sage 1996) 107-118.

33 Hedley Bull, The Anarchical Society: A Study of Order in World Politics (Columbia University Press 2012).

34 Vanessa Pupavac, 'War on the couch: the emotionology of the new international security paradigm' (2004) 7(2) European Journal of Social Theory 149.

35 Little and Rogers (n 8).

36 Cathy Caruth, Unclaimed Experience: Trauma, Narrative, and History (Johns Hopkins University Press 1992). 
of memories. For Caruth, ${ }^{37}$ traumatic memory operates similarly for both individuals and cultural groups with regard to collective or cultural traumatic experience, for 'history, like trauma, is never simply one's own, that history is precisely the way we were implicated in each other's trauma'. This implies that the traumatic event can evoke a shared response across time, giving rise to a transhistorical or intergenerational effect.

For theorists such as Kirmayer, ${ }^{38}$ the interplay between individual and collective experience takes on a new significance. He has argued that the recollection of traumatic events is governed by social contexts and cultural models (possibilities) for memories, narratives and life stories. 39

Theories of trauma and the political provide a means of revisiting the Agreement in ways that foreground the importance of the affective turn, including an acknowledgment that issues of memory, legacy, responsibility and victimhood - insofar as they are mined by political parties to re-engage in the conflict by proxy - feed a cycle that can only be broken and interrupted by taking the affective dimension seriously. This is more than a therapeutic or individual concern. It is deeply political.

\section{THE TRAGIC CYCLE OF COLLECTIVE POST-CONFLICT TRAUMA}

In the normal course of post-conflict politics, an authoritative/hegemonic statesanctioned narrative succeeds in laying down a new social order, using strategies that include acts of forgetting and memorialisation. As a result, the realms of the political and contingency, trauma and war are projected by the new political order onto the 'outside' or the 'other', while sovereignty and order are restored 'inside'. There has been no such resolution in Northern Ireland after 1998.

The genius of the Agreement and the 'peace process' is also its outstanding challenge: namely, the management of the open wound of radical contingency, the risk of continued exposure to a series of contested foundational narratives of traumatic violence (and a repetition of attempts at their vindication, in a clear sign that the conflict is still alive). Below the surface of what passes for the day-to-day performance of a linear narrative of 'normal' politics in progress within the Northern Ireland Executive and Assembly is the unfinished business of conflict and interpretative contestation over preferred constitutional futures. The sovereign state, far from enjoying a hegemonic moment of imposing a new narrative order, is itself deeply engaged in managing its own among multiple competing narratives about the nature of the conflict and the legitimacy/illegitimacy of its use of force and political violence. Legacy and memory are mere currency in this ongoing transactional politics that sit somewhere between ongoing antagonism and agonism.

The profound role of trauma in this complex scenario has been explored by Jenny Edkins 40 in her work on the constitutive role of trauma in the political. She notes that our existence relies not only on our personal survival as individual beings but also on the continuance of the social order that gives our existence meaning and dignity: family, friends, political community, beliefs. If our social order betrays us, the meaning of our existence changes. ${ }^{41}$ Traumatic events are overwhelming, she writes, but they are also a

37 Ibid 15.

38 Laurence Kirmayer, 'Landscapes of memory: trauma, narrative, and dissociation' in Paul Antze and Michael Lambek (eds), In Tense Past: Cultural Essays in Trauma and Memory (Routledge 1996) 173.

39 Ibid 191.

40 Jenny Edkins, Trauma and the Memory of Politics (Cambridge University Press 2003).

41 Ibid 4. 
revelation. They can strip away commonly accepted meanings by which we lead our lives in our various communities. They reveal the contingency of the social order and, in some cases, how it conceals its own impossibility: 'They question our settled assumptions about who we might be as humans and what we might be capable of.' ${ }^{32}$

In a counterintuitive move, Edkins argues that the re-inscription of trauma and traumatic events into linear history generally depoliticises and gentrifies this experience. She argues:

Memory and forgetting are crucial, both in contesting the depoliticization that goes under the name of politics, and in keeping open a space for a genuine political challenge by encircling the trauma rather than attempting to gentrify it. ${ }^{43}$

Edkins' excavation of the connection between trauma and acts of sovereign constitution is at once deeply provocative and essential for examining the current politics of Northern Ireland. Edkins poses the question of how contemporary forms of political community, such as the modern state, have an 'ironic connection' with traumatic events. She demonstrates this by exploring the connections between violence, the effects of trauma, and forms of political community, drawing on her interests in the formation of sovereign power and western subjectivity or personhood. With debts to Michel Foucault and Jacques Lacan, Edkins conceives power as, above all, a relationship and is interested in the intersection of state power and the experience of trauma:

Forms of statehood in contemporary society, as forms of political community, are themselves produced and reproduced through social practices, including practices of trauma and memory. ${ }^{44}$

Critically, the political is understood here as that which enjoins us not to forget the traumatic real but rather to acknowledge the constituted and provisional nature of what we call social reality. Politics, on the other hand, refers to the institutions and practices that belong to our imagined 'social reality'. The political is that which takes place at moments of major upheaval and discontinuity - hegemonic transitions - that precede the replacement of new social and legal orders. ${ }^{45}$

\section{The journey from antagonism to agonism}

One of the criticisms of the liberal approach to peace processes is an inclination towards depoliticisation or denial of the continuing salience of power. In stark contrast, the work of Chantal Mouffe on agonism foregrounds the continuous processes of hegemonic ascendance and decline and the ever-present factor of conflict in all politics.

The agon in agonism means struggle and is associated with the writings of Friedrich Nietzsche, Hannah Arendt and contemporary political theorists including Bill Connolly and Chantal Mouffe, who have introduced the discussion on agonism to conceptualise the conditions and possibilities of freedom that must be constantly negotiated, navigated and reconstructed as social orders rise and fall on tides of hegemonic constellations of power.

Hegemony is a deeply relational concept of power, referring to the capacity and mechanisms, including law, ideology and culture, used by a dominant group in society to exert influence over a subjugated group. ${ }^{46}$ Each moment of sovereign enactment of power

42 Ibid 5.

43 Ibid 16.

44 Ibid 11.

45 Ibid 12-13.

46 Terry Eagleton, Ideology: An Introduction (Verso 1991). 
and identity is implicated in a perpetual negotiation with contingency (traversing the realms of the political and politics) ${ }^{47}$ followed by narrations of security, social order and identity. For agonists, identities - no matter how ancient, how powerful - are always in translation, always holding out, but never fully secured by totalising impulses in the face of social conflict and pluralisation (identity/difference). Democracy is, above all, the creation of conditions for conflict to find its expression in agonistic terms rather than the inevitable creation of a reconciled society. 48 This is precisely the nuanced positioning that was invoked by the Agreement but, for reasons that we have explored, has been under-analysed. ${ }^{49}$

For Mouffe and others writing in this radical tradition, the key is to embrace a point of view that acknowledges conflict as integral to social life and always amenable to transformation from destructive to constructive approaches. In her reading of societal order, we have to relinquish the idea of a society beyond division and power and come to terms with the lack of a final ground; undecidability. For Mouffe, a radical negativity impedes the full totalisation of society because each order can only achieve a passing hegemonic grip in the face of the ever-present possibility of antagonism. Mouffe understands the political as the ontological realm where antagonism plays a constitutive role in forming human societies. In contrast, the realm of politics refers to that ensemble of practices and institutions upon which a specific hegemonic order is constructed. Recognising each social order as such means that society must be envisaged as the product of a series of practices aimed at establishing order in a context of contingency, a context of ever-shifting accretions of power.

\section{Discussion}

In Northern Ireland, the demands of the democratic journey from antagonism to agonism are exceptional insofar as the Agreement marks a threshold moment in the overarching relationships between Dublin, London and Belfast. O'Leary ${ }^{50}$ goes so far as to venture that the 1998 Agreement appeared to end British political colonialism in Ireland, adding that the informed Irish nationalist understanding was that Northern Ireland's current status as part of the United Kingdom was now a function of Irish choices, not merely the outcome of past British conquest or imposition. It seemed that the new arrangements, with their proto-federal-like structures, provided for mutually interconnected institutions protected by the two sovereign governments. However, expectations that both governments would continue to act impartially, and in good faith, as co-guarantors of the principles and institutions at the heart of the Agreement have been strained by unilateral positions adopted by the United Kingdom government, including those proposed in the course of its negotiations with the European Union on the terms of its withdrawal. Indeed, Harvey ${ }^{51}$ has observed 'a staggering degree of constitutional irresponsibility' on the part of the United Kingdom government in the wake of the 2016 referendum on exiting the European Union. While acknowledging that leaving the European Union is a distinct issue, he recalls that respect for the principle of consent is supposed to be central to the new constitutionalism of Northern Ireland.

47 Mouffe (n 6).

48 Chantal Mouffe, in Nico Carpentier and Bart Cammarerts, 'Hegemony, democracy, agonism and journalism: an interview with Chantal Mouffe' (2006) 7(6) Journalism Studies 964 <eprints.lse.ac.uk>.

49 Ibid 9.

50 O’Leary (n 11) 308-309.

51 Colin Harvey, 'Complex constitutionalism in a pluralist UK' (Constitutional Law Blog 2 July 2016)

$<$ https://ukconstitutionallaw.org/>. 
Uncertainties around the United Kingdom government's commitments to the Agreement have amplified and radicalised the uncertainties built into the Agreement itself, reinforcing fractures between the dominant unionist and nationalist parties in Northern Ireland. Suspended between a politics of antagonism and agonism, the dominant ethnonationalist parties of Northern Ireland have not put their most fundamental constitutional differences behind them but pursue their preferences - directly and indirectly - in a series of proxy policy arenas, from Brexit to the COVID-19 pandemic.

Today, it seems that two political scenarios hover, spectre-like, over the public square in Northern Ireland, as initial plans for the 100-year anniversary are debated just as calls for referendums and conversations about the shape of a new 'shared island' 52 proliferate. These are:

- the prevailing status quo marked by dominant and often antagonistic unionist/nationalist/republican party discourses of constitutional contestation predicated on a tacit acknowledgment of political uncertainty (unionists tend to regard contingency and uncertainty through the lens of lost hegemony, 'insecurity' and extreme caution given their deep ontic investment in the status quo; while nationalists/republicans openly seek to test the limits of contingency); and

- divergent responses to the contingent nature of the Agreement map on to responses to the prospect of a high-stakes test of preferred constitutional preferences in 'border polls'. ${ }^{53}$ Whereas political unionism has, for the most part, sided with the British government in resisting or deferring proposals to set an early date for a referendum on the future status of Northern Ireland (given their comfort with the status quo), nationalists/republicans have begun to actively prepare and press for such a poll in each jurisdiction (Northern Ireland and the Republic of Ireland), ${ }^{54}$ one in Northern Ireland as early as 22 May 2023 (the 25th anniversary of the ratification of the Agreement). ${ }^{55}$ Some have even criticised the Irish government's Shared Island Unit and the proposal of the Taoiseach, Michael Martin, to delay calling for a border poll for at least five years. ${ }^{56}$

This article posits a third, emergent, scenario. One that does not rule out the prospect of polls (sooner or later) but which seeks to draw attention to the unfinished work of addressing the full implications of the radical contingency that is implicit in the

52 Following the General Election of 2019 in the Republic of Ireland, the Taoiseach's Office established a 'shared island' unit to consider the Irish government's role in facilitating peaceful change in line with the Belfast-Good Friday Agreement.

53 The Belfast Agreement, Schedule 1 (Polls for the Purpose of Section 1), outlines United Kingdom legislative provision for the Northern Ireland Secretary of State to direct the holding of a poll. The Agreement states that Northern Ireland shall not cease to be part of the United Kingdom without the consent of a majority of the people in Northern Ireland voting in a poll. Referendums would take place in both Northern Ireland and, later, in the Republic of Ireland if ratification of a Northern Ireland poll outcome with constitutional implications for the Republic is required.

54 Oireachtas Joint Committee of the Implementation of the Good Friday Agreement, Brexit and the Future of Ireland: Uniting Ireland and its People in Peace and Prosperity (Seanad Éireann Report 2017).

55 'Queen's professor Colin Harvey proposes date for Irish unity polls' Belfast Telegraph (Belfast 29 November 2020) <www.belfasttelegraph.co.uk/news/northern-ireland/queens-professor-colin-harvey-proposes-datefor-irish-unity-polls-38738151.html>.

56 James Ward, 'Irish border poll not on agenda for next five years, says Micheál Martin' Irish Times (Dublin 23 October 2020). 
architecture of the Agreement. This third scenario posits the possibility of working towards conditions where:

- the Agreement is understood as a structuring process - bringing the affective and the cognitive dimensions of consciousness and relationality into dialogue - and bearing forth the conditions of possibility for the emergence of an as-yetunimagined/nor fully articulated constitutional destination for the island that while respecting the binary ('either/or') nature of referendums - valorises first and foremost a will to novelty and improvisation, and mutual constitutional coauthorship enabled by a politics of agonism. This scenario will require not only political and institutional forms but an affective turn, notably that which addresses and recognises the formative role of societal trauma and its implication in contested narrativity on the threshold of state formation.

The full power of the Agreement escapes us, in the absence of a complex understanding that an affective dimension must accompany our attempts to understand communities' experience of traumatic conflict and the role of trauma in mediating attempts to navigate contested narratives-as-histories in conditions of contingency. The recovery of complex agency is wagered on this belated engagement with the psychic fallout and suffering that has resulted from a prolonged political conflict. The conflict has tragically touched the lives and families of citizens and leading political representatives across the spectrum.

Insofar as the Agreement straddles what Mouffe has described as the political and politics, part of the outstanding challenge of implementation is the role of acknowledging and understanding the formative role of collective post-conflict trauma and how it is associated with histories of political violence at the boundaries of (geo)politics ('the political') and the internal workings of a state ('politics'). Where the democratic ethos of a society emerging from conflict is ill-prepared to navigate between the realm of the political and politics, in conditions of radical contingency, there is an ongoing risk that experience of violence, recrimination and accusations will continue to be instrumentalised (even weaponised in a rhetorical sense) as parties to the conflict seek out ways to conduct conflict by proxy, even using opportunities afforded by notionally democratic arrangements (power sharing). These practices, characterised by antagonism, give rise to the cyclical and repetitive behaviours and responses closely associated with 'trauma time', 57 in the absence of the emergence of an agreed or authoritative political narrative of a new social order. In the interim, the challenge is to agree conditions for what the President of Ireland, Michael D Higgins, has described as an ethics of remembering and narrative hospitality; a radical challenge in the face of uncertainty. Drawing on the works of Hannah Arendt, Paul Ricoeur and Richard Kearney, the President has addressed the challenges of this 'Decade of Centenaries' in terms of different narratives of violence recalled and the absolutisms that drove those impulses to violence together with the careless assumptions of 'the Other'. Urging citizens to understand that we are concerned with a very tentative horizon of completion, of a critical historical knowledge aware of its limitations, and built on such a reconciliation of narratives that avoids binary opposites, he recalls Paul Ricoeur's observation that between history's project of truth and memory's aim of faithfulness is a small miracle of

57 Rebecca Graff-McRae, Remembering and Forgetting 1916: Commemoration and Conflict in Post-peace Process Ireland (Irish Academic Press 2010). 
recognition that has no equivalent in history. That which must come to be shared lies beyond history or memory. 58

Edkins $^{59}$ describes the role of the state in mediating foundational violence and drawing a narrative veil over its role in securing a new social order. The contingent nature of the Agreement interrupts the state's ability to pursue a conventional pattern of authoritative state-sponsored forgetting/narrativity as part of an attempt to reinscribe a convincing linear narration of social order and politics per se. This interruption results in an ongoing cyclical pattern of contested and antagonistic narrativity associated with the political, including attempts to instrumentalise issues of contested history, memory, legacy processes and memorialisation. The contingent nature of the Agreement - with the open-ended prospect of fundamental constitutional change - continues to interrupt any prospect of drawing a veil over contested foundational narrative histories; memory, legacy and memorialisation have, instead, become absorbed into and have been instrumentalised in unresolved antagonism. Indeed, the prospect of a referendum itself has become one of the subjects of an antagonistic dispute over the meaning of the Agreement, with some challenging the legitimacy of calls for a poll on grounds that it may provoke a violent response or undermine a thin reconciliation. The debate on the timing of a referendum clearly evokes discursive invocations of the political and a discursive tactical preparedness to leverage influence by invoking this realm of the traumatic. Calls for preparation of a border poll are met, for the moment, by some responses that are characteristic of a deep residual antagonism associated with a denial of the rights of those who wish to advocate for such preparations.

\section{Conclusion}

With a growing appreciation for the importance of emotions in politics and law, this article has drawn attention to the particular role of societal trauma in a polity where the most fundamental questions of constitutional decisions remain radically contingent and open, due to the nature of the Belfast-Good Friday Agreement. The role of trauma is a central mediator of the connection that individuals make with collective or societal narratives, and this experience, in turn, is heavily influenced by the available cultural and political contexts. In conditions of complexity and radical contingency, the individual experience of trauma clashes with the requirement for critical responsiveness and a dialogical orientation required to complete the journey from antagonism to constructive, democratic agonism. Personal and collective trauma is associated with a tendency to retreat to and fix categories, and with a refusal to accommodate the political positions adopted by 'others'. Far from an openness to narrative hospitality and improvisation, trauma can drive a will-to-control and fix that which appears already present and objective.

Considering the question of the multiple Strands or scales involved in the Agreement, we have noted a tension within Strand One (within Northern Ireland) where a counterfactual liberal tendency to anticipate a consensus-based teleology that might one day produce reconciliation has encouraged a virtuous but misleading expectation that normal ('bread and butter') devolution-style politics can be achieved. We have concluded that the continuing - and likely increasing re-engagement - of the United Kingdom and

58 Michael D Higgins, President, 'Of centenaries and the hospitality necessary in reflecting on memory, history and forgiveness' (Speech on Centenary Commemorations, 4 December 2020)

$<$ https://president.ie/en/media-library/speeches/of-centenaries-and-the-hospitality-necessary-in-reflectingon-memory-history-and-forgiveness $>$.

59 Edkins (n 40). 
Republic of Ireland governments in managing the uncertainties embedded in the Agreement will remain vital for the evolution of politics within Northern Ireland if a recidivist tendency to lapse back into sectarianism is to be avoided. The roles of the two governments will be paramount in managing and mediating the political conditions for the Strand One actors, as calls mount for a referendum on the future constitutional status of Northern Ireland. The Agreement, more than anything, took its present form because the political theatre of Northern Ireland - prior to 1998 - was unable to safeguard the space in which antagonistic social forces have failed to subdue one another. In such conditions it was always unlikely that the journey from antagonism to respectful agonistic politics could be achieved, due to an incomplete experience of agency in the context of a conflict that has origins and continuing salience for players and conditions that lie beyond the region's territory. Brexit has turned out to be an exemplary case study in a geopolitical transition, rooted in England's long post-imperial decline and subsequent failure to fully integrate into the European Union project, which has begun to trigger farreaching ramifications for the constitutional 'settlement' with the devolved nations of the United Kingdom. Brexit has demonstrated that the Agreement - perhaps best understood as a complex legal order - acts as a catalyst and agentic supplement for parties normally limited in their field of influence within Northern Ireland. The Agreement bestows complex and empowered agency on political players by institutionalising, albeit in an agonistic fashion, hard and soft power obligations by a complex network of actors, from Dublin to London, and from, Brussels to Washington, mediating designed and emergent structures to articulate a new balance of interests between parties within Northern Ireland in ways that reflect the ongoing shifts in hegemonic power at the level of geopolitics. The most effective players from Northern Ireland will embrace the structuring possibilities of the Agreement as an invitation to cultivate and embrace a distinct 'culture of feeling' or felt understanding for the navigation of the meaning of such hegemonic shifts, by working across all three Strands of the Agreement.

We have drawn, primarily, from the work of Edkins for a far-reaching insight into the formative role of trauma in the constitution of sovereign political power and the dimension of the political or the realm of 'war and peace'. Using her framework, we can closely observe the predicament of Northern Ireland, which currently occupies a position of suspension between war and peace: a suspension between the realm of the radically contingent where narrativity is exposed as undecidable, and where expectations of a normal linear social order are continually confounded. The outstanding challenge for parties to the Agreement remains the management of the open wound of radical contingency, the risk of continued exposure to a series of contested foundational narratives of traumatic violence and their capture/utilisation by political entrepreneurs seeking to win vindication for a new bid for a hegemonic social order. This activity involves both non-state and state actors. Where these actors continue to engage as ethnic entrepreneurs, there is a continuing risk that profound matters such as the management of conflict legacy and support for a generous and plural respect for conflict memories are drawn into a transactional vortex, resulting in their translation into a currency for a new round of conflict.

If Edkins is correct in her basic thesis, that forms of statehood in contemporary society, as forms of political community, are produced and reproduced through social practices, including practices of trauma and memory, we may need to revisit the implications for Northern Ireland, given its suspended status somewhere between the political and politics, somewhere between war and peace. The test, it seems, will be to cultivate an affective politics - looking beyond the liberal expectation of consensus - to 
a more post- or metamodern form of political practice that embraces radical contingency and uncertainty and can live more at ease with the constituted and provisional nature of social reality. This would entail a significant shift in the tone and quality of political discourse within Northern Ireland, and one that is probably only viable within the political imaginary sustained by the complex field of political identity/difference held by the Agreement. It will mean a radical cultivation of institutional and affective conditions for a tolerance of uncertainty and contingency, and a respectful agonism that extends to an easy contemplation of far-reaching constitutional possibilities. It will mean an explicit public understanding and recognition that each sovereign enactment of power and identity is always implicated in a perpetual negotiation with contingency from which narratives of social order, security and identity are never more than moments of disambiguation.

Identities are always in translation, notably those dimensions of identity that found themselves on temporary hegemonic moments in the sun. An acknowledgment that conflict is always with us, that accretions of power have no final resting place, can be embraced as liberating - given the appropriate affective orientation - in a spirit of critical responsiveness, with a radical commitment that goes beyond mere pluralism/tolerance and extends to practices of pluralisation. This is a societal investment in extending the horizons for the emergence of new identities and new conditions of possibility that liberates everyone in a politics of becoming where the promise is a coming-into-freedom.

The unfolding and uncertain ramifications of Brexit for the United Kingdom's continuing obligations to the Agreement present a real challenge to our third scenario that envisages the Agreement as a structuring possibility - bearing forth the conditions of possibility for the emergence of an as-yet-unimagined constitutional destination, informed by a will to novelty in a spirit of improvisation. This uncertainty is balanced by the interventions sponsored by the Republic of Ireland's government in the form of the Shared Island dialogues and $€ 500$ million investment in connecting infrastructure and people across the island. One innovative and deliberative possibility for a significant civic society contribution is an all-island Citizens' Assembly, a variation on a model that has been instrumental in facilitating far-reaching policy shifts ${ }^{60}$ within the Republic of Ireland, including decisions with constitutional implications. ${ }^{61}$

Significant interventions have also been led by the President, Michael D Higgins, who has made calls for ethical remembering and narrative hospitality a cornerstone of his mandate. The President has recently outlined some of the thinking that lies behind the 'Shared Island' initiative that is part of the current Programme for Government (2020). He invites citizens to revisit their conceptions of what constitutes a real republic - a republic that would have solidarity, community and the public world at its heart; a republic fit for a shared island of diverse tradition, hopes and loyalties and one that would acknowledge the state not only as benign, but as active, as a shared responsibility for the common welfare of all.

These conversations, including the affective responses they engender, will be important in setting the tone and conditions for any challenging initiative, such as a

60 Mandated by the Irish Parliament - Dáil Éireann - the Citizens' Assembly convened between 2016 and 2018 forwarded recommendations to the Dáil on the equal right to life of a pregnant woman and her baby (Eighth Amendment to the Constitution), ageing, fixed-term parliaments, the conduct of referenda and climate change. The Citizens' Assembly website is available here <www.citizensassembly.ie/en/>.

61 A Citizens' Assembly is one of the recommendations for consideration set out in Interim Report of the Working Group on Unification Referendums on the Island of Ireland (The Constitution Unit, University College London, November 2020). 
referendum on Northern Ireland's constitutional future. A test for all those advocating such a referendum will be the avoidance of a conflation of the binary nature of the referendum process with an expectation that any outcome should follow a binary logic. Our third scenario offers the possibility of a more compelling vision of constitutional change as a threshold in time for the creation of a space for multiple belongings.

Drawing from the inspiration of James Joyce, Kearney adds that a philosophy of 'twinsome minds' - the way of thinking that informed the Belfast-Good Friday Agreement of 1998 - suggests that the key to the way forward is to regard the Agreement as a promissory note that may only deliver by holding a working through, holding a space for the complex, crossed identities and lost aspirations of those who have grown up 'in between', whose stories risk being eclipsed by 'monumental history'. ${ }^{62}$ In a commentary on the importance of 'good commemoration', the authors look to a way beyond 'pathological polarities of either/or towards an open culture of both/and'.

Agonism as an achievement of living in the deep present must also move forward as a set of embodied practices - as a mutually affective orientation - and inform a non-violent emergence (qua co-authorship) of open-ended and unprecedented constitutional futuresin-solution - not as a conflict over pre-scribed templates ('a United Ireland' versus 'the United Kingdom') but as an emergence of hybrid arrangements, perhaps without precedent, that carry forward the intentions, practices, transformed narratives and complex multi-layered identities and affiliations that seek accommodation in an, as yet, unimagined constitutional framework.

This is work with multiple dimensions, in the realms of identity and affect alongside their retrospective codification in new forms of institutions, as yet unimagined. Legal orders re-imagined in all their affective and complex dimensions offer the possibility for reimagining liberty that is much less invested in control and closure and committed to improvisation and adaptation. Transforming the quality of conversation in a system means transforming the quality of relationship and thought - and it is this transformed quality that travels with us into the emerging future. 